\title{
Power to $X$ - green hydrogen for electrical energy and fuel, for production and products
}

\author{
Jochen Lehmann ${ }^{1, *}$, Thomas Luschtinetz ${ }^{1}$, and Johannes Gulden ${ }^{1}$ \\ ${ }^{1}$ Stralsund University of Applied Science, Institute of Renewable Energy Systems, 18435 Stralsund, Germany
}

\begin{abstract}
Basing on the figure "Power to Hydrogen / Power to Gas", shown by the authors at the last HTRSE conference, this time it will be illustrated, that green hydrogen - produced with renewable energy has the potential to become a basic material in the economy at general instead of fossil one. Synergies are available. But the low price of hydrogen produced via steam reformation of natural gas prevents to reach business cases for environment friendly products as long as the European laws and regulations do not support production and use of green hydrogen for instance by a tax for $\mathrm{CO}_{2}$ emission.
\end{abstract}

\section{Introduction}

It seems that not only Germany will miss the goals of reduction of $\mathrm{CO}_{2}$-emissions by 2025 . Up to now the main ways to try it have been: The reduction of special production ways, saving heat, using more and more natural gas, renewable energy sources, biomass and biogas as well.

Much more possibilities will become opened by the use of green hydrogen according to Fig.1. Large effects could be activated besides of the energy sector. (All the green hydrogen issues one can find easily in the compendium edited by J. Töpler [1]).

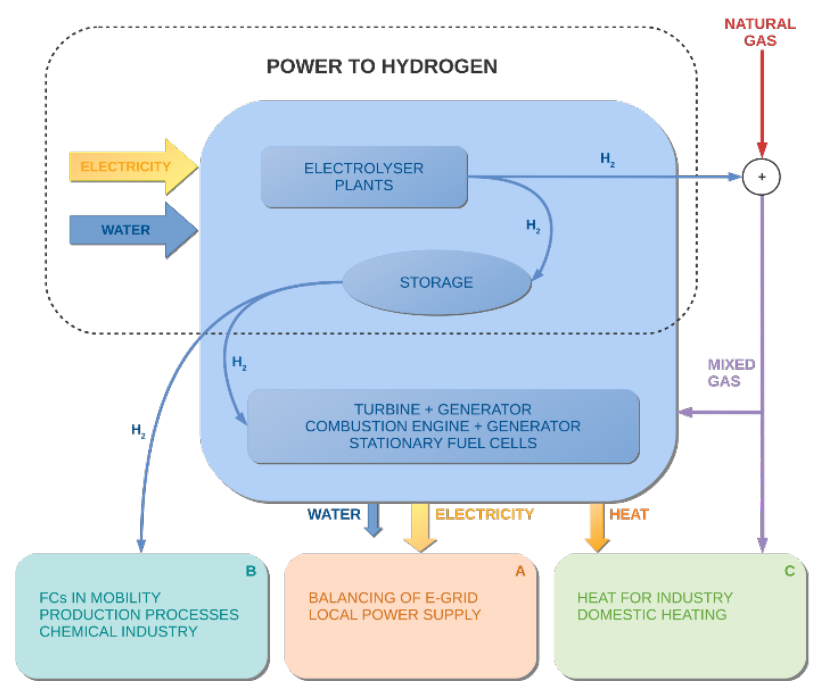

Fig. 1. Power to $X$ on the base of electrolysis.

\section{The Field of Electricity (A)}

Mostly the harvest of renewable energies happens as electricity: Photovoltaic and wind (in growing parts), water power (not with a volatile characteristic, the enlargement of its part is complicated), high temperature thermo solar in hot countries, wave energy, and some others. In case of feed in of changing current into the grid, we know, more than $30 \%$ of it will make the voltage and the frequency inconstant. We have to equalize the changing, and we have to sorrow for backup power in case of deficits (night, calm, etc.). For that purpose, back-up power stations are used on the base of fossils up to now.

To reduce the $\mathrm{CO}_{2}$, we should do it in a clean way in the future. And in very large scales (may be seasonal equalisation). That will be possible via power to hydrogen only [2]. On the other hand, that method is an ideal one for building stand-alone systems and for a clean emergency supply. To improve the efficiency, the process heat should be used.

All the components are available or become developed such as low and high temperature fuel cells, hydrogen burning intern combustion engines and gas turbines.

\section{Traffic and Production (B)}

The need of seasonal hydrogen storage means, that there will become constructed hydrogen factories (Fig.2).

These have to electrolyse and to store hydrogen, and to act like back-up power stations delivering electricity into the grid in case of a lack between demand and supply.

For their own stability the factories could and should sell a second product - hydrogen as a material.

Besides of the Stralsund installation as a model there are two " $\mathrm{H}_{2}$-factories" in the north-east of Germany: Prenzlau (500 kW electrolysis) since 2011 and Grapzow (1 MW electrolysis) opened 2013. Three years later started the plant near Mainz with three 1.5-MW-PEMelectrolysers new developed by Siemens [4]. All they are not able to operate rentable, according to the current law, 
that both the electricity from the windmills and the delivering of reconverted current as backup power have to be taxed.

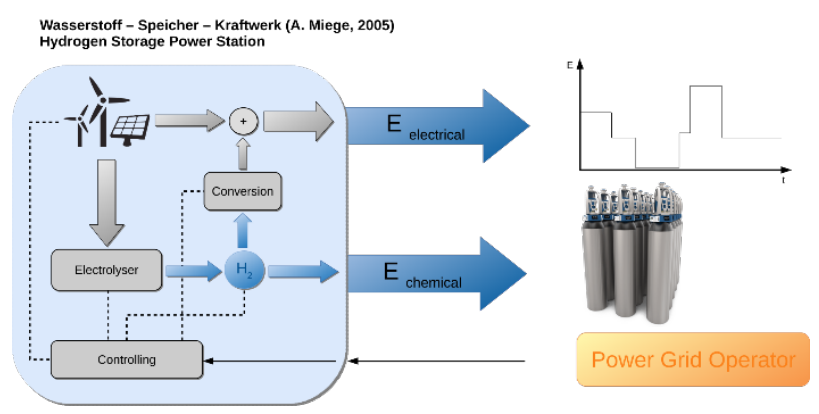

Fig. 2. Hydrogen Storage Power Station - " $\mathrm{H}_{2}$-Factory" [3].

A similar problem the green hydrogen finds in case of selling it as a fuel. But some consumers are asking for the hydrogen fuel already:

In the year 2013 Hyundai started the series production of its fuel-cell-VAN, Toyota and Honda followed. FC-busses one can buy in China. The competing enterprises hesitate with a larger number of such vehicles.

The first FC-train started in the German public railway service this year. Some more will follow definitely. And the use of fuel cells for powering trucks and heavy street engines seems to come. Established on the market are FC powered fork lifters produced by Linde and Toyota.

One of the general problems of hydrogen as a fuel in the mobility is the small density of hydrogen connected with a small volumetric energy density. Therefore, the laboratories developed liquids contending much hydrogen as partner in the compounds under the topic "Power to Liquid".

On board of the consumer one need a reformer, setting free hydrogen for fuelling. The discharged material has to be transported back to the producer for forming new the LOHC-material. The advantage of the LOHC's is the best hydrogen density next of the metal hydrides. [5]

All together: That is a good development, but a quite slow one.

Therefore, the working group "performing energy" (a part of the German Hydrogen and Fuel Cell Association [6]) is consequently engaged to find more possibilities for the use of green hydrogen. For instance, the production of Diesel with green hydrogen instead of fossil one would be a case for support by the Brussels rules. On the other hand: Such a large demand of green hydrogen would help to develop a powerful electrolyser industry as the base for the future hydrogen economy.

A second idea is directed to the same goal: Within the steel production the ore has to become reduced by burning coke or natural gas in a newer procedure. Also this step could be realised by hydrogen [7].

Hydrogen is a partner in lots of reactions and compounds. Making all these "greener" means that all the prices will raise. The consumers should be open to pay it, finally a $\mathrm{CO}_{2}$-tax they will have to pay too.

\section{Heat for Industry and Houses (C)}

Hydrogen coming out of the electrolyser fed in directly into a natural gas pipe - that is the shortest way to the heat market. According to actual regulations less than 3 $\%$ are allowed. That should not bring any problems for the heating systems; the burning value is a little bit lower. For intern combustion engines about $30 \%$ hydrogen in the mixture should be acceptable, the power of the engines becomes reduced. A problem could be to hold a constant relation from natural gas and hydrogen in a large pipe system.

Powering heat turbines with mixed gas is thinkable for a period, but in the end turbines should be proof for $100 \%$ hydrogen.

Of course: It is possible to add a methanisation step and put the product into the natural gas pipe. The disadvantage would be the reduction of the total efficiency.

Producing green heat one should use the thermo solar technique, the burning of biomass, and the geothermal energy, of course. Under special conditions catalytic hydrogen burners for cooking and heating are good options [8]. In that case the fuel is pure hydrogen.

At general it is to notice, that the greenest heat is saving heat. Better constructing and more isolating will bring the best effects for heating and cooling. But that is a very large task.

By the way: One of the basic ideas of the world first wind-hydrogen-project by Olof Tegström (1985/6) has been to produce hot water for heating the single house, the second one the electrolysis and hydrogen storing for cooking and powering the car (reported in [9]). But the general proposal to use "surplus" wind power for heating - "Power to Heat" - seems not to be the best, storing it as hydrogen opens better possibilities.

\section{Summary}

"Power to $\mathrm{X}$ " is a very complex connection of procedures basing all together on the conversion of renewable energies into green hydrogen by electrolysis. This procedure is good for the smallest up to the largest scale.

The gas hydrogen is storable in four different ways: Pressured or liquefied, insides of metal hydride alloys or as a partner of chemical compounds. These characteristics and the fact, that hydrogen and water reactions are building a circuit as the main feature of the sustainability, are making the gas to a material of universal interest for the future economy.

It should be able to better the world, making lower CO2-emissions, creating jobs and national wealth, reducing the demand of natural oil and gas, and deescalate the political situation.

\section{References}

1. Johannes Töpler et. al., Hydrogen and Fuel Cell, ISBN 978-3-662-44971-42007, Springer, 2016 
2. F. Crotogino, R. Hamelmann, „Wasserstoffspeicherung zur Glättung des Windangebots“, XIV. Energie-Symposium, Stralsund, Proc. 11-17 (Quoted and discussed in: HTRSE-2014, Proc. 309), 2007

3. J. Lehmann, O. Luschtinetz, A. Miege, H. Sandlaß, C. Sponholz, Vergleichsmäßigungsstudie im Auftrag Energieministerium MV, Hochschule Stralsund, 2005

4. M. Kopp u.a., "Energiepark Mainz Betriebserfahrungen", XXIII. Energie-Symposium, Stralsund, Proc. 80-84, 2016

5. J. Gulden, et. al., "New means of hydrogen storage", to be held at the HTRSE 2018
6. Performing energy, www.dwv-info.de, 2018

7. M. Hölling et. al., "Stahlerzeugung mit grünem Wasserstoff”, HZwei 03/2018, 34/35, 2018

8. Ulf-Peter Großmann u.a., "A non-stationary hydrogen cooker with MH storage", Int.J.of Hydrogen Energy 25-1, 87-90, 2000

9. L. Voss, et. al., "Erinnerung", XXIV. EnergieSymposium, Stralsund, Proc. 229-234, 2017

All the proceedings of the Stralsund conferences you can find:

https://www.hochschule-stralsund.de/forschung-undtransfer/institute/institut-fuer-regenerativeenergiesysteme/ 